\title{
A POTENTIAL MATING DISRUPTION SYSTEM FOR THREE NEW ZEALAND LEAFROLLER SPECIES
}

\author{
L.M. COLE ${ }^{1}$, J.T.S. WALKER ${ }^{1}$, A.M. EL-SAYED ${ }^{2}$, P.L. LO ${ }^{1}$ and \\ N. SHARMA ${ }^{1}$
}

\author{
${ }^{1}$ The New Zealand Institute for Plant \& Food Research Limited (Plant \& Food \\ Research), Private Bag 1401, Havelock North, New Zealand \\ ${ }^{2}$ Plant \& Food Research, P.O. Box 51, Lincoln, Canterbury, New Zealand
}

Corresponding author: lcole@hortresearch.co.nz

\begin{abstract}
A dispenser incorporating a pheromone blend to disrupt three species of New Zealand leafrollers was developed for their control in Otago summerfruit orchards. This control system was evaluated for suppression of leafroller activity in Hawke's Bay apple and summerfruit orchards over 2 years. In 2007-8, dispensers were applied at 600-1000/ha in two large organic apple orchards and activity of all three species in pheromone traps was recorded. Dispensers achieved only $73.8 \%$ and $61 \%$ shut-down of lightbrown apple moth pheromone traps in Orchards A and B respectively. Dispensers were modified to increase disruption of this species and were evaluated in similar trials on the same orchards in 2008-9, and achieved $98.4 \%$ and $90.9 \%$ trap shut-down respectively. The same dispenser was also evaluated on four summerfruit orchards, where it was applied to 1 ha plots in January 2009 at 1000 dispensers/ha. Pheromone trap catches of lightbrown apple moth were reduced by $83.3-100 \%$ over the following 3 months. Further assessment of this multiple species mating disruption system is required to determine its value in managing the fruit damage and larval infestation risks to meet export market tolerances.
\end{abstract}

\section{USING LUREM-TR TO TRAP THRIPS IN GLASSHOUSE CROPS IN VICTORIA, AUSTRALIA}

\author{
C.M. TILL ${ }^{1}$, R.C. BUTLER ${ }^{1}$, P.A. HORNE ${ }^{2}$, N. HIVES ${ }^{2}$ and \\ D.A.J. TEULON ${ }^{1}$
}

\author{
${ }^{1}$ The New Zealand Institute for Plant \& Food Research Limited, Private Bag \\ 4704, Christchurch, New Zealand \\ ${ }^{2}$ IPM Technologies Pty Ltd, P.O. Box 560, Hurstbridge, Victoria 3099, Australia \\ Corresponding author: tillc@crop.cri.nz
}

Trials were undertaken in glasshouse crops in Victoria, Australia, to test the effect of LUREM-TR on numbers of thrips trapped. LUREM-TR is a newly developed commercial thrips lure (especially for Frankliniella occidentalis (Pergande), Thrips tabaci (Lindeman) and Thrips major (Uzel)) and is used in greenhouses in Northern Europe. In 2008 LUREM-TR was trialled in a commercial rose glasshouse in Officer, Victoria, in October and a vegetable nursery glasshouse in Daylesford, Victoria, in October, November and December. In the rose greenhouse the numbers of thrips caught on blue sticky boards with LUREM-TR increased by $28 \%$ over 4 days. Additionally, a prototype lure in this glasshouse increased thrips capture by up to $68 \%$ over 2 days. In the vegetable nursery greenhouse the number of thrips on yellow sticky boards with LUREM-TR increased by up to $400 \%$ over 7 days. Differences in the effect of LUREM-TR on numbers of thrips trapped in these trials and other trials are discussed. 